\title{
Sprawozdanie z działalności Studenckiej Poradni Prawnej w Instytucie Prawa i Ekonomii na Uniwersytecie Pedagogicznym w Krakowie
}

Leges sine moribus vanae Prawa bez moralności gina.

Funkcjonowanie systemu prawnego nie może być całkowicie pozbawione wyżej wspomnianej moralności. Zacytowana paremia oddaje ducha fundamentów naszej działalności od początku istnienia poradni uniwersyteckiej. Można jednakże wysunąć przeciwstawną teorię, iż prawo bez moralności istnieje, ale jakim jest prawem? ${ }^{1}$

Studencka Poradnia Prawna powstała w 2018 roku. Początkowo opiekunami poradni byłam ja oraz dr Marcin Mazgaj. Nasze założenie było proste: zwiększyć znaczenie wysokiego poziomu merytorycznego na kierunku prawo, poprzez upraktycznienie kierunku i zaangażowanie studentów prawa w szeroko pojęte praktyczne stosowanie prawa. Mieliśmy pewne obawy, np.: jak poradnia zostanie przyjęta przez swoich potencjalnych klientów. Szybko jednak zniknęły, kiedy z sukcesem zakończyliśmy naszą pierwszą sprawę. Później pojawiły się kolejne i z upływem czasu dostrzegliśmy sens naszej pracy i ogromny potencjał niesienia pomocy wszystkim tym, którzy nie byli w stanie odpłatnie skorzystać $\mathrm{z}$ oferowanej pomocy prawnej na rynku prawniczym.

Po roku intensywnego rozwoju poradni, naszym głównym opiekunem został Pan Profesor Grzegorz Krawiec, a nasz zespół wsparli dr Ariel Mucha oraz dr Piotr Uhma. Poradnia została podzielona na cztery sekcje: cywilną, administracyjną, karną i gospodarczą. Łącznie w poradni pracuje ok. 20 studentów. Od początku istnienia pomogliśmy w ponad 30 sprawach. Przeważają głównie sprawy z zakresu prawa rodzinnego, choć podczas pandemii gwałtownie przybyło nam spraw z zakresu prawa pracy.

1 Dr Łucja Kobroń-Gąsiorowska, adwokat, Koordynator Studenckiej Poradni Prawnej w Instytucie Prawa i Ekonomii, Uniwersytet Pedagogiczny im. Edukacji Komisji Narodowej w Krakowie. 
Na szczególną uwagę i podziw zasługuje ogromne zaangażowanie naszych studentów w pomoc wszystkim potrzebującym bezpłatnego wsparcia prawnego. Muszę przyznać, że poradnia to przede wszystkim studenci, co więcej, ich wysoki poziom merytoryczny sprawia, że poradnia cieszy się ogromną popularnością. Wprowadzone przez nas usprawnienia działania poradni oraz kampania marketingowa, sprawiły, że z miesiąca na miesiąc zyskała na znaczeniu wśród klientów poradni. Nowością, która wyróżniła naszą poradnię na tle innych, to porady $\mathrm{w}$ formie online. Okres pandemii sprawił, że byliśmy w pełni przygotowani do świadczenia darmowej pomocy prawnej najbardziej potrzebującym, którzy ucierpieli w związku z zaistniałą sytuacją.

Wiemy, że wraz z nowym rokiem akademickim 2020/21 czekają nas wciąż nowe wyzwania $\mathrm{w}$ zakresie maksymalizowania profesjonalizmu udzielanej przez nas pomocy prawnej. Wierzymy również, że stawimy czoła nowym wyzwaniom dzięki zgranemu zespołowi kadry koordynującej oraz wspaniałym studentom.

Wszystkich zainteresowanych poznaniem nas i naszej działalności zapraszamy na nasz profil na facebooku oraz instagramie:

- facebook: @studencka poradnia prawna UP

- instagram: studenckaporadniaprawnaup

- adres mailowy: poradnia@up.krakow.pl. 